\title{
Being Left Behind Amidst Africa's Rising Imagery: The Maasai In The World Of Information And Communication Technologies (ICTs)
}

\author{
Eric E. Otenyo
}

Northern Arizona University

Eric.Otenyo@nau.edu

\section{Abstract}

Today the media is replete with stories about Africa rising and enjoying middle -income status. Those promoting the narrative of Africa rising include the World Bank and western -trained elites. The narrative of success assumes that prosperity trickles down to Indigenous communities, who are pictured consuming mobile phones and tablets. At the same time, Hollywood and western media outlets continue to present images of Indigenous Maasai as a cultural export to be consumed. With emphasis on social media narratives, this paper interrogates the continued marginalisation of the Maasai people amidst the myth of a rising Africa. In sum, the Africa rising myth and penetration of ICTs in rural areas masks the dispossession of Maasai means of livelihood, and therefore worsening the groups' conditions of living.

Keywords: Maasai; Social Media; ICTs; Africa Rising; Indigenous people

\section{Introduction}

This paper explores aspects of the critical issues that affect the everyday experiences of the Maasai community. Scholars in the area of development studies regard inequities in resources between Indigenous and non-indigenous communities to be apparent and exacerbated through economic systems that hold back the disadvantaged communities. A hallmark of the new economy is the increased use in information and communication technologies (ICTs), which include mobile phones, now available among Maasai (Santos, 2010). Although these devices are gaining popularity and have contributed to economic growth, there is evidence that problems exist in the manner in which growth benefits are shared in emerging economies. Efforts to improve the living conditions of historically marginalised communities have failed to serve all the disadvantaged groups. One key reason is the structure of the international political economy.

By promoting the use of ICTs in development, policy makers have not sufficiently addressed the global implications of the two opposed forces of, (a) integrating Indigenous communities in the increasingly globalised new economies and (b) resolving the long-standing exploitation of wealth belonging to Indigenous groups. Without striking a balance of meeting the demands of Indigenous communities, and encouraging them to be a part of the ICT-led emerging economy, it is difficult to see how economic growth and rising incomes in developing countries of Africa serve the interest of historically oppressed and neglected groups.

The global faith in the ability of ICTs to communicate the success stories of marginalised communities has to be interrogated along the equally compelling discourse of the desire to promote justice for historical wrongs meted against Indigenous groups, including the Maasai of East Africa. This line of thinking also allows for reflection on the roles of social media and other ICTs in human rights activism and mobilisation for political and economic development in marginalised communities. The predicament to be discussed revolves around the uses of ICTs for service to Indigenous tribes against the possibility that the benefits from the emerging economic miracles have not done much to change their depravity. This study is abased on accumulated data about how Maasai fit in the now established but also contested narrative that Africa is rising within a globalised and networked world system. 


\subsection{Methods}

The study area included Kajiado, Ngong, and the environs of Nairobi. A few Maasai people living in Western Kenya, specifically Vihiga County were also interviewed, as a focus group and asked to share their stories concerning the uses of ICTs and reasons for moving away from their homelands. The discussions followed research protocols and none of the interviews was coerced or bribed to share their stories.

In addition, documentary work touching on Maasai dispossession was identified and utilised. The paper also draws on historical and cultural data and personal observations by the author, who spent summer 2015 in Kenya. Major themes embodied in cultural studies include the relationship between identities and the material and social conditions within which Maasai live. This research makes meaning of the social realities of Maasai people, especially as is shaped by the growing proliferation of ICTs.

Also, much work on Maasai is now founding documentary films, YouTube, Instagram, Facebook, WhatsApp, Twitter, LinkedIn, YouTube, Snapchat, Google +, blogs, wikis, and other social media platforms. Granted that Internet as Marshall and Rossman (2016, p.30), ethnography is now a legitimate social science and since there is increased use of mobile phones among indigenous people, such resources advance our understanding of their everyday experiences. Therefore, the research made use of Internet resources including researcherseeking clarifications (through e-mail, and computer -mediated SMS tools available on Mobile phones) on material facts covered on online daily newspapers, magazines, blogs, and as a tool for gathering supplementary data.

In addition, the context of the Internet as an area though which to analyse the structure and negotiated meaning of what constitutes Indigenous Maasai rights informs much of the discussion about the intersection between ICTs, political activism and development in Maasai land. This is not surprising, as Markham (2004) suggests, the Internet is both a tool and a discursive milieu that facilitates the researchers' ability to understand the construction of social structures, and I add, especially, those in which identity politics is of central importance.

\subsection{The Setting}

The Maasai number and are considered as Africa's most visible group. The Maasai community is frequently mentioned in the same sentence with tourism in Kenya and Tanzania. Indeed, Maasai land is home to some of the most popular tourist attractions in the region including the Maasai Mara, Serengeti, Ngorongoro, Amboseli and Tanrangire game parks. According to the Maasai Association (2015), the group's population stands at over 1 million, spread through Kenya and Tanzania. Although the bulk of Maasai live in Kenya, census data on numbers in Tanzania are hard to come by because the government there does not ethicise census data collection. It is estimated that Maasai lands cover over 160,ooo square kilometers. The Maasai society is comprised of sixteen chapters (Iloshon): listed on the Maasai Association's website as follows: "Ildamat, Ilpurko, Ilkeekonyokie, Iloitai, Ilkaputiei, Ilkankere, Isiria, Ilmoitanik, Iloodokilani, Iloitokitoki, Ilarusa, Ilmatatapato, Ilwuasinkishu, Kore, Parakuyu, and Ilkisonko, also known as Isikirari (of Tanzania).

Debates over which African groups qualify to be included among the world's indigenous people never questioned the legitimate inclusion of the Maasai. And in East Africa, events marking the UN declaration of decade of the World's Indigenous People (1995-2004), acknowledged the groups political and economic marginalisation. Most observers acknowledged that the Maasai way of life was a factor and modes of production in the state's discriminatory practices. Importantly, their land rights were denied and openly brushed aside from broader questions of human rights in both Kenya and Tanzania.

\subsection{The Literature and Media Narratives on a Rising Africa}

The proliferation of ICTs has helped nurture a growing myth of Africa rising from its long stupor in dark ages. Yet, the mythology being built around Africa's entry into the global markets of consumption of high-end goods and services are not always interrogated within the 
scholarly community. It is frequently an act of wishful thinking on the part of the ruling elite, whose ideas mirror those of global owners of capital and international finance. Thus, the promise of good life for a majority of Africans must be deconstructed in light of empirical realities.

No doubt, the myth of the rising Africa has roots in the global search for markets and control of resources. The reality that ICTs spread to the interior of Kenya and ingrained in its social and economic life is applauded. There are at least two streams of literature that shape the discourse on development in indigenous African communities. In simple form these are the same arguments about Afro pessimism and optimism as projected through increased consumption of mobile phone and other computer-mediated ICTs.

Observations on Afro-optimism, and the view that Africa's image is changing exist in popular media and scholarly literature (Nothias, 2014). Negative stereotypes on lingering violence and continuing poverty have been replaced by positive images of a more hopeful African future (Sieff, 2008; Taylor, 2014). According to the Economist (2011), Africa had the fastest growing economy and had real chance to follow in the footsteps of Asia. Africa's middle class is said to provide customers for manufactured goods. A similar narrative suggests international companies are looking to Africa as the best market for investments (Walt, 2014). Those studying the factors that have led to increases in GDP are quick to point at the boom in technology use in the continent (Perry, 2012). Others like Clark (2013) remark that Africa's renaissance exists but it deserves the support from developed countries. The World Bank adds fuel to this narrative by suggesting poverty reduction in Africa s taking place (Devarajan, 2012; World Bank, 2014). And there are also suggestions that the prosperity excludes girls, women, and the youth (Drummond, Thakoor and Yu, 2014; Lagarde, 2014; Saba, 2014; Yahya, 2015).

Still, the most significant doubts about the rise of Africa has also come from observers in the business sector who consider the poor infrastructure, corruption and weak political institutions as real barriers to Africa rising. Sieff (2014), Mohammed (2015) and Johnson (2015) call into question the veracity of the claims of Africa rising. They, for various reasons, dismiss the emerging unrealistic assumption of improved economic growth serving as a catalyst to improved lives of Africans. Most of the claims of prosperity in Africa are naively associated with the rise of ICTs, especially the ease at which mobile phones facilitate communications in previously unreached areas. And we also know that increased presence of indigenous communities on social media has been mistaken for social development without digging deeper into the underlying assumptions of the claims.

Oxfam (2015) offers the most significant insights in raising the question about who benefits from the increased economic outputs? Oxfam contends that the growth benefits foreign businesses and not the well being of most African indigenous groups. From a theoretical perspective, Hong (2015) notes that simply acknowledging the rise of Africa misses out the point that millions of the poorest Africans have not benefitted from the growth in GDP.

Assuming that both Afro-pessimists and those optimistic about Africa rising are looking at different places, a partial understanding of the plight of Indigenous communities paints a better picture of the theoretical contributions for assertions that Africa's rise is a myth. Work done on Indigenous communities shows the limits to the Africa rising narrative and the reinforcement of these communities as cogs in the wheel of a skewed globalisation machine that creates preordained winners in the name of ruling elites and their overseers in the corporate world. One is tempted to say that the basis for using information and communication technologies to bring together Indigenous communities into the development narrative is to minimise the fact that these devices do not change the power relations among different communities and nations. And there is little evidence to support the logic of spreading human development among all communities. The structures that promote images of Maasai and other Indigenous groups utilising ICTs are also the same structures that promote their conditions of depravity and marginalisation. In the next section, I make observations and report the core finding about the predicaments of the Maasai as they navigate through state and corporate controlled new economies of East Africa. 


\section{Observations and Results}

For Indigenous people, the administrative state traditionally lacks the will to support human development in these communities. State apparatus also do not place values on Indigenous rights to exist in whichever ways that uplift the marginalised. If anything, state apparatus undermines the survival of Indigenous communities and, are in fact, using ICTs to further exclude the Maasai and other Indigenous communities. The theoretical argument is that ICTs reinforce existing power structures and do not change the economic position of marginalised groups.

As a result, the Maasai, compared to other groups are still among the largest offline groups. The systematic deprivation of Maasai is accentuated through online apparatus. This is not hard to visualise. State and corporate governance structures exclude the Indigenous leaving them out of the decision-making channels. When much of the decision making over Indigenous resources is conducted over digital devices, access to decision channels by those affected becomes necessary.

Yet current corporate practices present barriers in terms of relevance of the contents conveyed through the digital devices. Not to mention the charges for data usage and move toward cashless economy. For instance, Maasai cattle traders are captured moving their trade items but lacking the sophistication to utilise modern applications of the cashless economy.

In addition, the state sells some of the data about the Maasai and their immediate environs to tourist and travel agencies. However, the state does not share the foreign exchange earnings with Maasai communities in any meaningful ways. Further, the state has no laws to protect Maasai from exploitation of their identity. Its claim to uphold human rights and constitutionalism falls flat considering that trust between the government and Maasai communities is far fetched. The Maasai are not allowed to kill lions that maraud their cattle, and if they do so, it is front-page news and a matter of popular culture entertainments. Compensation for wildlife destruction of Maasai Savanah, is never treated as a matter of urgency.

Compensation for destruction of flora and fauna in Maasai neighborhoods is not budgeted for in tourism budgets. Despite state failure to compensate Maasai for the destruction of their means to livelihood, the blogospheres tout virtues of digitalisation of the Maasai economy. Instead, the narrative is that Maasai need Apps to help them track down their cattle. But the big picture is lost. And just how have these ICTs been a part of the everyday realities in Maasai lands?

\section{Social Media and Identity Politics}

The effects of social media on Indigenous cultures are a fairly new area of academic interest and is gaining momentum, for example pioneering scholarship Carlson (2013) and Rice, Haynes, Royce, \& Thompson (2016). Carlson's exemplary work posits that "social media is a new frontier for Indigenous people to represent and identify themselves and to others in the emerging global amphitheater" (2013, p.148). Focusing on Australian Aboriginal people, she articulates the view that Facebook and other social media offers space and platforms for confirmation and demonstration of one's identity and public recognition. To effectively use social media platforms, Indigenous communities are working with other groups to seize the moment and take advantage of the strengths of the new applications. As tools for communication, social media platforms enable discussions to occur around goals. In the case of Maasai, they function to inform the policymaking publics, including international allies wishing to fight for the inclusion of Indigenous people's in national prosperity and cultural survival. In fact, Ackerman and Krupp (2016) described an organisational behaviour model of using social media that includes sharing ideas and encouraging international awareness and learning. From a political perspective, additional goals have recently included activism, especially to the empowerment of women, whose well-being is adversely impacted by discrimination through the denial of educational opportunities and cultural practices like 
female genital mutilation (FGM), practiced among Maasai tribes. And there are several ways through which social media highlights the condition of Maasai. In describing ways in which social media has been applied, one must recognise that governments also use social media, to present a different reality of the Indigenous lives.

For starters, success stories of prominent "Maasai" are widely circulated on social media. For instance, Professor George Saitoli, was vice president and mathematician PhD at University of Warwick, likewise, the experiences of Kenya's second Vice-President Joseph Murumbi and former Speaker of the House of Representative, Francis Ole Kaparo and freedom fighter and successful Member of Parliament, prominent land owners John Keen and William Ole Ntimama were frequently presented as Maasai icons. More recently, former Permanent Secretary for Education James Ole Kipiapi who ran for election President of the Republic of Kenya in 2013 were presented in the media as role models. The reality is that these individuals are a small minority of the ruling national cosmopolitan elite. These individuals do not represent the Middle within the Maasai Moran traditional culture. Because Kenya's political system is heavily ethnicised, there is the temptation to present the success of a few wealthy individuals as a symbolic mirror of the larger impoverished tribal base. In some ways, the assumption here is that notion of an individual's success tells the story of his or her community and that there are no boundaries between community and its leaders. Thus, for example, an ethnic Maasai tribesman being named Minister for Education is a big deal for the thousands of starving and marginalised Maasai. Evidence suggests that the co-opted rich Maasai are not human rights activists advocating for protection of the interests of the poor tribesmen. Perhaps, this is a classic case of the elite reconstructing their identity, as accounted for in the literature discussing groups modernising and leaving behind their old ways (e.g. Harris, 2013, p. 14). As a result of the neglect of rights of the less fortunate, the material conditions in vast areas of Indigenous counties are worsening rather than improving.

As stated above, Kenya's political landscape is paved on ethnicity. These clashes have mostly been about land. In 2004 and 2005, for example, Maasai villagers invaded private ranches in Laikipia District and fought against Kikuyu farmers in Mai Mahiu. At least 40 people died in the 2005 ethnic clashes. The government rejected the Maasai claims to their lands. Periodic skirmishes have continued in the Rift Valley regions. And after the ethnic clashes which followed the 2007 presidential election, the National Cohesion and Integration Commission (NCIC) was formed. The commission aimed at promoting cohesion among the different ethnicities. The commission targeted hate speech and mobilisation, especially, that presented on social media. The commission chairman, Francis ole Kaparo, a Maasai acknowledged the role of elite mobilisation through social media outlets. Following escalation of conflicts in the post-2007 era, some of which targeted the Maasai and Samburu cattle owners (Gitonga, 2015). But there was little evidence that Maasai leaders in Kenya used social media to articulate cases of land deprivations as was done in Tanzania. Interpretation over Maasai land agreements with British settlers in areas such as Laikipia are an issue that remains unresolved.

\subsection{Popular Culture and Stereotypes: Maasai as Warrior Narrative}

Another action that deserves mention is the misrepresentation of the Maasai men as brave defenders of the nation or tribe. The popular culture continues to present Maasai men as warriors, killing lions to impress women suitors. Hollywood moviemakers have taken notice of this illusionary depiction of an entire tribe and captured it in movies like Lion King, and in Out of Africa, adopted from Sal Dinesa's 1972 book.

The corporate mentality was to update the stereotypes of the tribe as cultural artifacts to be enjoyed. This predates contemporary Hollywood caricatures. In 1908 and 1949, a documentary depicted Maasai hunting lions. The video is shown on the Serengeti's Channel of YouTube (YouTube, 2011). Later, the movie Bomba, the Jungle Boy presented in a comical way a Maasai warrior killing a male lion (See, YouTube, 2007). Other clips followed, e.g. Lion vs. Maasai, Amboseli National Park, Safari Kenya, (YouTube, 2015). 
Other online, YouTube media presentations continue to depict the Maasai as entertainment objects. For instance, "Maasai attacked by lioness" is entertaining for large audiences. The description in a video uploaded on May 11, 2010 states:

An unlucky Maasai warrior gets chased and then pounced by a ferocious lioness (who was the culprit for killing their livestock, hence why they were hunting her), whom he and his fellow warriors cornered on some kopjes. He becomes seriously injured, and eventually dies from his injuries (YouTube, 2010).

As of August 2016, more than 2.9 million people viewed the video. For some, Maasai on YouTube and social media signifies an emerging information revolution in Sub Saharan Africa (Bhan, 2013). Bhan cautions that presenting Maasai images on social media should not promote "stale imagery" of the past.

Other YouTube images of the Maasai advance a similar narrative, for example, the movie The White Maasai Trailer based on Corinne Hofman's autobiographical Internet video work, the Maasai: The Rain Warriors directed by Pascal Plisson, Film Essays of Maasai Life, (Creative Cowboy Film), and the Maasai: From Sand to Snow, a documentary movie are among those uploaded from DVDs. For one observer, John Kariuki (2003), the Maasai were the new 'Red Indians' of Hollywood. This intensity at which Maasai people are featured in movies, reifies the commercialisation of their cultures based on stereotypical presentations as morans (warriors). The marketisation of Indigenous cultures is reinforced by sophisticated branding techniques, which makes Maasai images, captured in digital devices a commodity.

\subsection{Brand Maasai}

There are several examples that shed light on this phenomenon. Journalist Cordelia Hebblethwaite (2013) reported that one Isaac ole Tialolo, a Maasai elder and chair of the Maasai Intellectual Property Initiative proposed that it was time the thousands of Maasai products like beads and dress be protected as a brand. Ole Tialolo argued that:

We all know that we have been exploited by people who just come around, take pictures and benefit from it.” We have been exploited by so many things you cannot imagine." Tourists take photos of Maasai people, in many instances against the will of those being photographed. In Ole Tiaolo's words, the Maasai equate illegal photographing of their people to taking their blood. ...We believed that if somebody takes your photograph, he has already taken your blood (Hebblethwaite 2013).

Further, the abuse of Maasai culture is perpetuated in thousands of online Travel Magazines without any direct benefits for the community. The problem is compounded by the fact that some of the images and video clips embedded in these online magazines are redistributed in multiple social media outlets. According to Light Years IP, a London based non-profit organisation, which specialises in protecting intellectual property rights; about 80 companies around the world use the Maasai image. It has formulated a policy known as Intellectual Property Value Capture to change rules on global trade involving people in developing countries (Light Year, 2014).

By many estimates, Maasai is the biggest cultural brand in the world. New Zealander, Ron Layton, founder of Light Years IP, estimated that if Maasai "brand" "were owned by a corporation, it would be worth more than $\$ 10$ million a year" (Hebblethwaite, 2013). Among the corporations that have utilised Maasai images include accessories branded Maasai made for British automobile company, Jaguar Land Rover and Maasai Barefoot Technology that produces specialty trainers. Also, the high-end fashion house Louis Vuitton manufactures a Maasai line, that includes hats, scarves, duffle bags, and beach towels (Hebblethwaite, 2013). Maasai Shukas (Toga) inspired the designers of the scarves. Other fashion companies that have been inspired by Maasai artifacts include Bedding shirts by Calvin Klein, and trousers by Ralph Lauren. Furthermore, in 2003, Italian pen maker, Delta introduced as part of its Indigenous People luxury line, a red and brown luxury fountain pen that retailed at $\$ 600$ (Faris, 2013). These are just a few examples of the commercial value of brand Maasai that corporations exploit at the expense of the dignity of an Indigenous people. 
So, if brand Maasai can make billions of dollars for international corporations, just how much do the Maasai people make? Probably nothing. The argument presented by the corporate world is that there is no unified body of Maasai body for corporations to seek permission from.

The Maasai brand was also manifest in local tourist circuits. For instance, the Maasai Mara is one of the best-known game lodges in the world. Through numerous travel magazines and the use of social media platforms like Facebook, it is promoted as one of the greatest places from which to experience the Wildebeest migration, an event considered as one of the world's most fascinating natural wonders, an African Safari Mecca of sorts. The Maasai Mara is home to the Big Cats like Lions, Cheetahs, Leopards, and other exotic mammals. It is also rich in flora and fauna and visitors may view the game on hot air balloons. Through increased human activity that includes deforestation, grazing, farming and land development, the ecosystem in the region is now threatened. Yet, the Narok county, where the Maasai Mara Lodge is situated collects millions of dollars, most of which is not reinvested in the region. In many instances, tourists have to pay in American dollars or other hard currencies signifying the externalisation of the Maasai Mara economy. Moreover, for several years, the education system ignored elements of sustainability that would have incorporated Maasai cultural lifestyles and Indigenous knowledge.

And, still part of the tourist attraction is the continued reification of the narrative that the Maasai are a people to be "experienced." Even famous conservationists like the Karen Blixen Camp promote their activities in a language, which commoditises the Maasai life style. The Karen Blixen Camp's website notes:

Experience how the Maasai people live in the middle of the bush with zebras grazing and lions roaring just outside their homes and get to know their culture and customs on a visit to the traditional Maasai village, the local primary school or the busty market day (Karen Blixen, 2015).

Karen Blixen states that it supports the Maasai community by encouraging its guests to visit the villages where Maasai live. Guests of Karen Blixen are required to obtain tickets before visiting Maasai villages. The fees collected are forwarded to the Maasai villagers for purposes of providing basic needs.

Besides the conservative educational initiatives, there are other efforts to use Smartphone technologies to promote environmental sustainability education. These efforts are meant to reengage the Maasai on issues of sustainability through modern pedagogical approaches (Dogbey et al., 2014). Using ICTs, for example, smartphones expand, visually the magnitude of the challenges of pastoralism but not succeed without massive support from all stakeholders. The government of Kenya, typically, controls the curriculum and leverage ICTs and experiential education systems only if such efforts contribute immediately toward foreign exchange earnings.

Although efforts by voluntary societies are on the increases, the economic gains, thus far, do not reflect the high visibility of the Indigenous community. In other words, Maasai per capita incomes are at the bottom among Kenyan communities. More important, the perpetuations of practices that reduce opportunities for advancement of women remain a huge challenge among development practitioners and scholars. Instead, the commodification of Maasai women has been reinvented through a unique set of circumstances, which brought Kenya on Hollywood's radar.

A Kenyan-Mexican, Lupita Nyongo won an Oscar Academy Award for Best Supporting Actress in her role as Patsey in Steve McQueen's drama 12 Years a Slave (2013). Because of her strong showing in popular media, she inadvertently contributed to the promotion of African dress and adornments. Inevitably, Maasai women were depicted in Lupita Nyongos's attire in many of her Hollywood-related media appearances. Her unintended consequence was to show the world that Maasai culture but at the same time lend credence to the marketability of Maasai as an artifact culture. Blogs and fashion Magazines all over the world gave glowing tributes to her dress, necklace and other outfits. In spite of the glamour, there was little interrogation of the 
material conditions that shaped the Maasai artistry or even the copyrights and rights of the Maasai women who have for generations mastered such fine works of arts.

\subsection{Making Good Use of E-Activism}

Beyond entertainment and branding, contrary to expectations and an unintended consequence of government promotion of ICTs, the use of these platforms for political mobilisation and engagement appears to be benefiting the Maasai. Among the reported success stories has been the use of blogs such as Cultural Survival, (www.culturalsurvival.org,) which advocates for indigenous people's rights on a global scale. Since 1972, this non-profit organisation has presented evidence of political marginalisation of indigenous groups across the nations. The platform includes blog posts from Maasai groups like the Maasai Education Discovery (MED), which has campaigned against female circumcision within the tribe. When embedded in social media like Facebook and Tweeter, posts from MED receive much needed publicity and to a small degree has influenced policy debates leading to greater state intervention in girl education within Maasai society.

Perhaps, a more pronounced social media -driven advocacy and form of e-activism was reported in the case of Tanzania. The Guardian Global Development, an online magazine, which is supported by Bill and Melinda Gates Foundation, has observed that social media actually helped the Maasai living in Loliondo, Tanzania to mobilise for a worthy cause-to save their land. The government in Tanzania had allocated land around the Serengeti National Park to a foreign hunting company in the early 1990s. In 1992, the government licensed a company owned by an official in the United Arab Emirates government, the Ortelo Business Corporation $(\mathrm{OBC})$ to organise hunting expeditions on the region.

Previously, in 1959 the colonial administration had designated the landmass a "Game Controlled Area." As a game area, rich in wildlife like lions, leopards, cheetahs, wildebeest, antelopes and other animals, it provided a perfect resource for sport and trophy hunters. What was ignored was the fact that for centuries, the Loliondo territory was home to pastoral Maasai.

The action to sell the land to foreigners ignored the calls from Maasai, whose community rights were not considered in the government decision. The Minister for Natural resources and Tourism allocated 150,000 hectares, which was 40 percent of the Loliondo, Ngorongoro District area to the hunting company, thereby attempting to evict over 20,000 people (Ngoitiko and Nelson, 2013). Sale of land would have been inconceivable in the early 1960s, when President Nyerere, through his Ujamaa (Community) doctrine would have never allowed land appropriation at the expense of Maasai community. Tolu Ogunlesi (2014), a Nigerian journalist quoting Mwalimu Nyerere (1962) book, stated:

In a country such as this, where, generally speaking, the African are poor and the foreigners are rich, it is quite possible that, within 80 or 100 years, if the poor African were allowed to sell his land, all the land in Tanzania would belong to wealthy immigrants, and the local people would be tenants.

In 2009, the Government of Tanzania evicted several hundreds of Maasai from their traditional homelands. This action was captured in local and international online and print media. Avaaz, an online activist organization posted information on this struggle for land rights and attracted more than 2.3 million worldwide supporters who signed the petition to the president. AVAAZ posted a petition to Tanzania's President Jakaya Kikwete:

As citizens from around the world, we call on you to oppose any attempt to evict Maasai from their traditional land or require them to relocate to make way for foreign hunters. We are counting on you to be a champion for your people and stop any attempt to change their land rights against their will (AVAAZ.org, 2023).

\section{Discussion}

The Moral Question that needs to be answered is whether Maasai are still being left behind amidst the narrative of a growing African middle class. Civil society groups framed as a 
question of human rights and mobilised accordingly. The global media coverage of the displacement of Maasai from their homelands forced the government to reverse its decision. There have also been other interventions geared toward transforming Maasai lifestyles and promotion of modernisation. In particular, international development agencies like FAO and UNDP attempts to push Maasai to live sedentary life styles have been praised by Westerntrained elite. Yet, there is evidence sedentarise Maasai projects have failed. Instead additional Indigenous land has been taken away. In Tanzania, the government evicted the Maasai from Simanjiro plains (McCarthy, 2013). And even after the High Court of Tanzania ruled in favor of Maasai, the government did little to compensate the groups from years of exploitation. The economic conditions remain intact and resources to provide sustainable development have dwindled. Efforts by Maasai for economic empowerment are not given the weight they deserve by way of helping market Maasai products. Maasai enterprises, with help from SHGW, a Dutch NGO, produce yoghurt, butter and ghee but these are not well promoted in local marketing avenues.

With the Maasai now at the heart of the Organization of Indigenous People's of Africa (OIPA), their informal economic settings are beginning to receive attention but their informal status exclude them from the market, upon which the narrative of Africa rising is rooted. Perhaps, this explains why the ICT mobile phone company, Airtel Tanzania, which is active in the Maasai regions of Tanzania offered to join UNESCO funded projects to construct boma housing units for the Maasai (Maduekwe, 2013). The goal of Airtel and other ICT corporations believe that formal housing units would provide incentives for women to set up small businesses. Having home implies better organisation for producing items such as handicrafts, raising chicken, selling milk and joining cooperatives (Maduekwe, 2013).

With the Maasai traditional homes taken away from them in the name of Serengeti National Park, Tsavo National Park, and Mkomazi Game Reserve, where is the reality of Maasai living? Outsiders, including large-scale hunting companies have been lured to Maasai life styles and encroached on the Indigenous people's wealth. If Maasai were a part of Africa rising why would a Maasai elder Martin Saning'o Kariongi from Northern Tanzania, make it his life mission to save his people's way of life? Maasai are not a part of the emerging narrative of the rising Africa when they have to be saving themselves.

The logic of the governments in Kenya and Tanzania is to continue to encourage commercialisation of an Indigenous people for purposes of gaining foreign exchange earnings. These governments do so without significant investments in the repair of the ecosystem. Conservation then has become more of the mission of Western research funds, the World Wildlife Fund (WWF) and volunteer non-profit conservatories like the Karen Blixen Camp. The Karen Blixen Camp, for example offers training to Maasai on sustainable ways to harvest honey. Investments in Maasai education are insufficient and not commensurate with tourist revenues from the community. The Karen Blixen Camp, is explicit on its website and provides the example of the Maasai predicament.

The Aitong Primary School is a Kenyan Government school and provides free education for the Maasai children. However, governmental funding has not been sufficient and well wishers as well as parents are contributing with financial support for teachers' salaries, school fees, construction of classrooms and basic learning aids (Karen Blixen Camp, 2015).

The case of Aitong is typical of all schools in the Maasai region. Without adequate funding, Maasai competitiveness and goals for navigating through the new economy driven by ICTs will not be achieved. Beyond appropriate funding for schools, the Maasai continue to be affected by acute shortages of water (Archambault, 2014). The Maasai are a community on the margins of survival, without land, water, and wireless, for the most part.

\subsection{Saving the Maasai through Digitisation of Culture}

Since 2008, efforts to digitise aspects of Maasai culture have been launched, albeit in a pilot scheme. Through the World Intellectual Property Organization (WIPO), Maasai can document 
their own values and archive key elements of their culture for future generations (Oppenneer, 2008). This collaborative approach included the Center for Documentary Studies (CDS) at Duke University, Library Congress, and WIPO. While archiving traditions is seen as "empowering" the tradition bearers, it does not transcend the ideas put forward in the reinforcements theories of the roles ICTs play in modern society. The question becomes, who controls the narrative about the Maasai? While the initiatives involve working with a few native Maasai, the cultural documentation project assumes the Maasai culture is under threat. The new economy has not altered the power structures and to confine Maasai to archives, which undergirds the Creative Heritage Project, of which the WIPO is a part of. The basis for digitisation seems to be an acknowledgement that the Maasai are a disappearing culture, yet the economic forces causing the situation are not interrogated in the process toward archiving the Maasai culture.

The same argument can be made with regard to formatting Maasai economies for further globalisation. This is in the form of IFAD taking action to manage Maasai adaptation of information and communication technologies through mapping their settlements with geographic information systems (Cordone, 2010). IFAD has established plans to not only use GIS to map the Maasai lands but also collect observations on herding and weather. On the surface, these ICTs appear as innocent ideas about reinforcing Maasai traditions and to assist the group in navigating through climate changes. Without adapting ICTs from below, there is the danger that resource management systems may not be sustainable. By involving elders from the Maasai community, the IFAD project seeks to help Maasai people to manage their rangeland in sustainable manner. Yet, the fundamental issues of education and ability the Tanzanian government to absorb and coordinate donor funded initiatives remains weak. While the IFAD grant seems reasonable, the government itself lacked the capacity to engage all the stakeholders in a sustainable way. Providing matching funds and successor programs, to be managed by the Maasai beneficiaries themselves seems a far shot.

A visit to Maasai land leads to discovery that the vast majority do not actually belong to the newfound lower middle class country status that Kenya is now a part of. Consider the education fraud boarding schools built for Samburu and Maasai - pastoralists were taken over buy other ethnic groups. If education is said to be a path for inclusion and tool for narrowing the digital divide, then how it has been provided for among the Maasai that resources must be channeled. This includes Maasai Mara University, to enable it be a catalyst in providing leadership on sustainable use of resources, including facilitation of ICT education among the indigenous pastoralist communities.

Above all, is a deliberate policy shift to stop the alienation of Maasai lands and to commercialisation of their culture? Maasai land is increasingly being alienated at alarming rates. It is predicted that the Maasai of Kajiado will become landless within a few years due to expansion of settlements and real estate developments associated with Nairobi's expansion (Koross, 2015). And when sold, it is often at below market prices. Witnesses, rich landowners, including ruling elite have built lodges in the Mara. And Chinese investors have also added to the stock of lodges in the Mara area. In fact, many of the land deals in the region are not legal. Adding to the mix are private "conservancies," funded directly by tourism interests including ventures by Richard Branson. It is reported that some of the land was leased for a throw-away amount of $\$ 27$ per hectare, per year (Hatcher, 2013).

Even government has underpaid Maasai for land appropriated for purposes of power station installations, railway and road construction. Already, protests of local Maasai over compensation have received much press coverage (Githaiga, 2015). Maasai herders have also protested against the Kenya Agriculture and Livestock Research and Organization (KALRO), which they claimed appropriated native land. The Maasai lost in an ensuing court case against the research center (Kipngenoh, 2015).

In addition, Maasai land is experiencing massive desertification through climate change and human caused destruction of biodiversity. Still, the destruction of the Maasai's natural resources through poaching of wildlife hunting, misappropriation of tourist dollars from the 
Maasai Lodges build within government national parks all deny the community the dollars to empower the communities. Further, Maasai lifestyle is a source of revenue for the Kenya Tourist Board, which actively promotes Maasai cultural artifacts and lifestyles as a commodity to be enjoyed by Western and Eastern tourists.

But in the collective minds of ruling elites, the Maasai are the undeserving poor. They need not join the middle class because they own cattle and are culturally comfortable in their environments. The myth of Africa rising does not include empowerment of those without Western education and those refusing to be part of the "logical western markets."

The origins of the exclusion of the Indigenous communities can be traced back to the early British settlements in Kenya. Not to forget to mention, that the Maasai homelands are in both Kenya and Tanzania, then, a German colony. The splitting of families across two different countries took its toll on cohesion and resourcefulness. The larger point, is, that the British planted the seeds for marginalisation of the community. The diaries and anthropological studies of the British colonisers are replete with comments that are derogatory of Maasai.

During the Lancaster House talks leading to independence, the issue of Maasai lands was raised. Everyone at the conference knew that Maasai land was communal and yet, the British and their African allies accepted to impose the market philosophy of "willing buyer-willing seller" against the wish of Maasai elders. As a result, illegal transaction involving a colonially instituted Lands Board processed transactions that gave huge chunks of land to British settlers in places such as, Elbourgon, Nyandarua, and Laikipia. Before independence, the Maasai leadership, through the Maasai United Front had termed the Kikuyu settlers as squatters. The Maasai also lost land to those building the Kenya -Uganda railway line, Magadi Soda Company and other mining corporations. As Mwaruvie (2009, p.45) sates, the corporations received favorable concessions at the expense of the Maasai community.

And after 1963, a good deal of the lands was dished out to President Jomo Kenyatta's henchmen. President Kenyatta gave away land extra constitutionally. Kenyatta assumed that his role as president was functionally equivalent to that of the Queen of England and he was only answerable to himself. After the British left, an emerging neo-colonial African elite continued along the same path, marginalising the Maasai and alienating them from their land. Witness, Nairobi itself means place of cold waters in Maasai language. Now accounting for over 60 percent of the country's GNP, Nairobi is hardly Maasai in character. Instead, it is modeled along the lines of the big cities of the west. Indeed, Mwalimu Julius Nyerere used to comment, tongue in cheek, that one does not have to go to London anymore, Nairobi would take care of the business. A good number of Maasai in Nairobi serve as night watchmen, sleeping on people's verandah's, out in the cold.

Later, government policy reiterated the idea of economic modernisation in Maasai land through extending individual property rights protections. And scholars joined in by offering explanations about the merits of indigenous management of their commons. For example, Mwangi, (2007) argued that Maasai pastoralists in Kajiado supported subdivision of group ranches, in the 1980s, as a strategy to their own rights to land. Bottom-line, Maasai wanted to be in charge of their own resources, especially land. Although the political support to Maasai rights was expressed through political rhetoric, the fundamental principles, based on marketisation of community lands held back the Maasai. In other words, the fundamentals of the economy did not match the rhetoric of development.

\section{Conclusion}

In conclusion, this study has described the nexus between ICTs supported by government and corporate power and the continued marginalisation of the Maasai. There is evidence that social media serves interests of all stakeholders in different ways. While on the one hand, ICTs help project the myth of Africa rising, paradoxically, new technologies help marginalised communities find voice to press forward with struggles for human rights. Bottom line, increased investments in ICTs must not be an end in themselves. Perhaps the exploitation of 
Maasai resources has to be rejected outright in view of African nationalism original objectives, which was to end all manner of discrimination and shared prosperity for all people. One is tempted to revisit Julius Nyerere's time tested observation that an increase in numbers of millionaires in a society doesn't amount to much if the system perpetuates the marginalisation of a huge segment of its people. According to Nyerere,

The appearance of millionaires in any society is no proof of its affluence; they can be produced by very poor countries like Tanzania just as well as by rich countries like the United States of America. For it is not efficiency of production, nor the amount of wealth in a country, which makes millionaires; it's the uneven distribution of what is produced (Nyerere 1962).

Therefore, the narrative of Africa rising, as perpetuated by the World Bank and local ruling elites is a disruption that masks the true motive of global capitalist goal, which is eradicate poverty through social engineering practices that end Indigenous cultures. And that is to drive them to the digitalised archives of history. The digitisation of Indigenous expressions, especially increased presence on social media, with the goal of promoting and passing along cultural heritage to succeeding generations recognises the utility of new technologies, but it also indirectly affirms that forces of destruction of these communities are real.

\section{References}

Ackerman, A.S., \& Krupp, M.L. (2016) "Puzzled by Social Media? Make Connections.” HR News, The Magazine of the International Public Management Association for Human Resources (IPMA-HR). (September): 12-13.

AVAAZ.org. (2013) Stand with the Maasai. AVAAZ.org: The World in Actin. Available at: http://www.avaaz.org [Accessed 8 April, 2016].

Bhan, N. (2012) Mobile phones, social media and the Maasai: Time to refresh the image. Blog. Available at: http://www.nitibhan.com [Accessed 24 May 2016].

Carlson, B. (2013). The 'new frontier': Emergent Indigenous identities and social media. In M. Harris, M. Nakata \& B. Carlson (Eds.), The Politics of Identity: Emerging Indigeneity (147-168). Sydney: University of Technology Sydney E-Press

Clark, H. (2013) Africa's renaissance deserves continued support. United Nations Development Programme. May 24. Available at: http://www.undp.org/content/undp/en/home/ourperspective/ourperspectivearticles/ 2013/05/24/african-renaissance-and-the-rising-south.html [Accessed 16 August 2016].

Cordone, A. (2010) Indigenous Maasai Cultural Center. Reinforcing traditional Maasai adaptation practices with information and communication Technology in the United Republic of Tanzania. International Fund for Agricultural Development, IFAD: Rome.

Devarajan, S. (2012) Africa is rising - is poverty falling? The World Bank. March 1. Available at: http://blogs.worldbank.org/africacan/africa-is-rising-is-poverty-falling [Accessed 12 March 2016].

Dinesen, I. (1972) Out of Africa, Vintage Books, New York. (First published in 1937).

Dogbey, J., Quigley, C., Che, M., \& Hallo, J. (2014) "Using Smartphone Technology in Environmental Sustainability Education: The case of the Maasai Mara Region in Kenya." IGI Global. 6 (1): DOI:10.4018/ijmbi2014010101.

Drummond, P., Thakoor, V. \& Yu, S. (2014) Africa Rising: Harnessing the Demographic Dividend. IMF Working Paper, WP/14/143. Available at: https://www.imf.org/external/pubs/ft/wp/2014/wp14143.pdf

Economist. (2011) "After decades of slow growth, Africa has a real chance to follow in the footsteps of Asia." (December 3), Available at: http://www.economist.com/node/21541015 [Accessed 3 June 2014]. 
Faris, S. (2013) Can a Tribe sue for Copyright? The Maasai want royalties for use of their name. October 24. Bloomberg News. Available at: http://www.bloomberg.com/bw/articles/2013-10-24/africas-maasai-tribe-seekroyalties-for-commercial-use-of-their-name [Accessed 2 July 2016].

Githaiga, P. (2015) “Locals Protest Compensation." Standard. July 15:28.

Gitonga, M. (2015) Professionals fanning conflict in Baragoi through social media, NCIC says. Daily Nation June 23. Available at: http://www.nation.co.ke [Accessed 24 June 2015].

Hebblethwaite, C. (2013) Brand Maasai: Why nomads might trademark their name. BBC News. May 28. PRI's The World. Available at: http://www.bbc.com [Accessed 12 July 2016].

Hong, H. (2015) "Africa rising”: A hopeless falsity or a hopeful reality? Undercurrent, 11(1): 16-22.

Harris, M. (2013) "Emergent Indigenous Identities: Rejecting the Need for Purity," in Harris, M., Nakata, M., \& Carlson, B. (Eds.). The Politics of Identity: Emerging Indigeneity. UTS Publishing, Sydney. 10-25.

Hatcher, J. (2013) “The Maasai Mara: It will not be long before it's gone.” The Guardian. Available at: http://www.theguardian.com/travel/2013/aug/23/masai-mara-tourismpolitics [Accessed 13 August 2016].

Johnson, S. (2015, October 27) Slowdown calls 'Africa rising' narrative into question. Financial Times. Available at: http://www.ft.com/cms/s/3/93d5c572-7bf6-11e5-a1fe567b37f8ob64.html [Accessed 27 October 2015].

Karen Blixen Camp, (2015) Community visits. Available at: http://www.karenblixencamp.com [Accessed 21 June 2016].

Kariuki, J. (2003) Maasai: The New Red Indians of Hollywood. The East African, Independent Weekly, Nairobi. March 3. World Press Review, 50 (5). Available at: http://www.worldpress.org/Africa/1063.cfm [Accessed 3 August, 2016].

Kipngenoh, B. (2015) Court restrains Maasai herders from land after failed agreement. Standard, August 13. Available at: http.www.standardmedia.co.ke [Accessed August 6, 2016].

Koross, K. (2015) How your new plot of land could be turning Maasai into Squatters. Standard, August 14. Available at: http://www.standardmedia.co.ke [Accessed 23 June 2016].

Lagarde, C. (2014) Africa Rising-Building to the Future (Keynote Address). International Monetary Fund. May 29. Available at: https://www.imf.org/external/np/speeches/2014/052914.htm [Accessed 29 May 2014].

Light Years (2014) About us. Available at: http://www.lightyearsip.net/news/ [Accessed 23 June 2016].

Louw-Vaudran, L. (2015) Africa: No Need to Panic - Africa Is Still Rising... Slowly. allAfrica. October 27. Available at: http://allafrica.com/stories/201510281438.html [Accessed27 October 2015].

Maasai Association, (2015) "Preserving and celebrating Maasai Cultural Heritage. "Available at: http://www.maasai-association .org/maasai.html [Accessed 3 August 2016].

Maduekwe, A. (2013) "A little technology can go a long way." Horizons, UNESCO Publication. A World of Science, 11 (2), April -June, Available at: http://www.unesco.org [Accessed 10 June 2015].

Markham, A.N. (2004) "Internet research, "in Silverman, D. (Ed.), Qualitative research (3 ${ }^{\text {rd }}$ edition), Sage, London. 111-128 
Marshall, C \& Rossnman, G.B. (2016) Designing Qualitative Research (6 ${ }^{\text {th }}$ ed.), Sage, Los Angeles.

McCarthy, D. (2013) Tribal elder modernizing the Maasai to avoid extinction CNN July 26. Available at: http://www.cnn.com [Accessed 3 August 2016].

Mohammed, O. (2015) Not everyone is buying into the "Africa Rising" narrative. Quartz. March 6. Available at: http://qz.com/397757/some-investors-are-not-fully-buyinginto-the-africa-rising-narrative/ [Accessed 6 March 2015].

Mwangi, E. (2007) Socio economic change and land use in Africa: The transformation of Property rights in Maasai land, Palgrave Macmillan, New York.

Mwaruvie, J. M. (2009) "Political Economy of Railway Development in Kenya," in Amutabi, M. N. (Eds.). Studies in the Economic History of Kenya: Land, Water, railways, Education, and Entrepreneurship, Edwin Mellen Press, Lewiston. 2976.

Ngoitiko, M. \& Nelson, F. (2013) What Africa can learn from Tanzania's remarkable Maasai lands rights victory. Guardian Global Development, October 8. Available at: http://theguardian.com [Accessed 16 June 2016].

Nothias, T. (2014) 'Rising', 'hopeful', 'new': Visualizing Africa in the age of globalization. Visual Communication, 13(3), 323-339. doi:10.1177/1470357214530063.

Nyerere, K. J. (1962) Ujamaa: The Basis of African Socialism. Available at: http://www.nathanielturner.com [Accessed 23 June 2016].

Oguniesi, T. (2014) Tanzania's Maasai prefer death to eviction. Opinion. November 23. Al Jazeera. Available at: http://www.aljazeera.com [Accessed 10 August 2016].

Oppenneer, M. (2008) Digitizing Indigenous Culture: the Maasai of Laikipya. WIPO Press Release, Geneva, Ethnos Project, May 20, 2008. PR/2008/553. Available at: http://www.ethnosproject.org [Accessed 12 June 2016].

OXFAM. (2015) Africa: Rising for the few. June 2. Available at: https://www.oxfam.org/sites/www.oxfam.org/files/world_economic_forum_wef.afric a_rising_for_the_few.pdf.

Perry, A. (2012) Africa rising. Time, 180 (23): 48-52.

Rice, E.S., Haynes, E., Royce, S.C., \& Thompson, S.C. (2016). Social Media and digital Technology use among Indigenous People in Australia: A literature review. International Journal for Equity in Health. 15:81. doi:10.1186/s12939-016-0366-o

Saba, M. (2014) Is Africa rising with women leading the way?, IC Publications Ltd, London.

Santos, R. (2010) “The Maasai tribe goes mobile," July 24. 2010 Global Marketing. Available at: http://www.2010global marketing.worldpress.com [Accessed 6 January 2016].

Sieff, M. (2008) Africa: Many hills to climb. World Policy Journal, 25(3):185-195. doi:10.1162/wopj.2008.25.3.185

Taylor, I. (2014) Is Africa rising? Brown Journal of World Affairs, 21(1): 143-161.

Walt, V. (2014) Is Africa's rise for real this time? Fortune. September 18. Available at: http://fortune.com/2014/o9/18/africas-rise-for-real-this-time/ [Accessed 18 September 2014].

World Bank. (2014) Africa Rising: A Tale of Growth, Inequality and Great Promise. April 14. Available at: http://www.worldbank.org/en/news/feature/2014/04/14/africa-rising-atale-of-growth-inequality-and-great-promise [Accessed 28 July 2016].

Yahya, M. (2015) A sidelined youth: The soft underbelly of 'Africa rising'. United Nations Development

Programme.

July

15 .

Available

at: 
http://www.undp.org/content/undp/en/home/blog/2015/7/16/A-marginalizedyouth-The-soft-underbelly-of-Africa-rising-.html [Accessed 3 May 2016].

YouTube, (2015) “Lion vs. Maasai, Amboseli National Park, Safari Kenya," February 23. Available at: https://www.youtube.com/watch?v=3djQlEPsL8k [Accessed 12 June 2016].

YouTube, (2007) "Maasai Warriors Kill Lion." Available at: https://www.youtube.com/watch?v=xe3syWtsMGs [Accessed 6 July 2016].

YouTube, (2007) January 26; "Maasai Warriors kill male Lion, Bomba, The Jungle Boy 1947," Available at: https://www.youtube.com/watch?v=xe3syWtsMGs [Accessed 16 July 2016].

YouTube, (2010) "Lion Attack! Get Wild." Available at: https://www.youtube.com/watch?v=6UnAMRiLGQg [Accessed 16 July 2016].

Copyright: (C) 2017 Otenyo. This is an open-access article distributed under the terms of the Creative Commons Attribution-NonCommercial 3.0 Australia License, which permits noncommercial use, distribution, and reproduction in any medium, provided the original author and AJIS are credited.

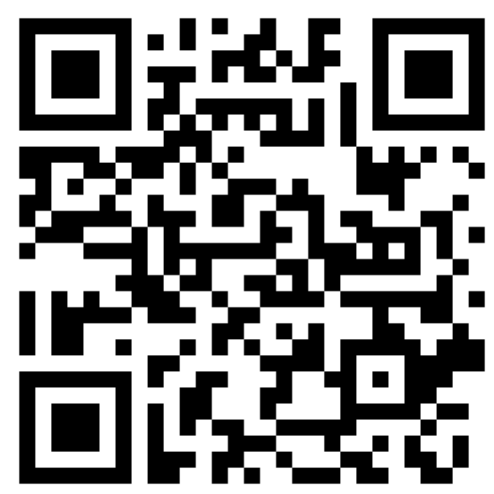

